\title{
ANALISIS DAMPAK PEMBANGUNAN TOL CISUMDAWU SEKSI 2 FASE 2 TERHADAP PEREKONOMIAN PENDUDUK SEKITAR (Studi Deskriptif Kualitatif Terhadap Penduduk Dusun Gawiru, Desa Girimukti, Kecamatan Sumedang Utara, Kabupaten Sumedang-Provinsi Jawa Barat)
}

\author{
TEGUH SANTOSA ${ }^{1}$, TRISNAWATI KUSUMAWARDHANI ${ }^{2}$ \\ teguh.santosa@ibm.ac.id ${ }^{\underline{1}}$ trisnawati@ibm.ac.id $\underline{2}$ \\ Program Studi Ekonomi Pembangunan ${ }^{1}$ \\ Program Studi Ilmu Komunikasi ${ }^{2}$ \\ Institut Bisnis Muhammadiyah Bekasi
}

\begin{abstract}
The construction of the Phase 2 Cisumdawu toll road, located in Gawiru Hamlet, Girimukti Village, Sumedang District, Sumedang Regency, West Java, has an impact on the surrounding population. Both positive and negative impacts. The positive impact is that the surrounding population is empowered to do work outside of project work such as cooking services, clothes washing services, mess cleaning services and project offices, daily warehouse clerk services (checking supplies of material goods), field survey implementers, security, foreman, local subcontractor, plagman. The negative impact is the lack of buyers for traders around Jalan Cadas Pangeran. Infrastructure development should be followed by human development. According to UNDP, indicators of the success of human development include 1) equity, namely equitable distribution of development results, equitable distribution to be able to easily access primary human needs (clothing, food, shelter), the need for health services that have now gone through BPJS, the need for education which is now running with the SPP-free program for state schools, 2) the ability of every human being to be productive according to their creativity and innovation, 3) empowerment, namely growth and human resource development that the government strives for. This study uses a qualitative methodology by conducting in-depth interviews, while the paradigm of this research is constructivism
\end{abstract}

Keywords: economy growth, micro economy

\section{PENDAHULUAN}

\section{Latar Belakang Masalah}

Pertambahan jumlah penduduk dari tahun ke tahun semakin meningkat, hal ini tentu akan menimbulkan dampak, baik dampak positif maupun dampak negatif. Dampak positif dari pertambahan jumlah penduduk diantaranya adalah dapat membantu perkembangan kegiatan produksi yang secara otomatis dapat meningkatkan perekonomian masyarakat. Adanya tuntutan pemenuhan akan barang-barang produksi dan barang-barang konsumsi, sehingga hal ini memerlukan jumlah tenaga kerja yang lebih banyak.

Adapun dampak negatif dari pertambahan jumlah penduduk adalah meningkatnya jumlah pengangguran usia muda, meningkatnya angka kejahatan, meningkatnya jumlah angka kemiskinan, banyaknya bermunculan pemukiman tidak layak huni (kumuh), menurunnya angka kesehatan terutama di pemukiman kumuh,.

Peningkatan jumlah penduduk juga berdampak kepada diperlukannya pembangunan infrastruktur yang dapat 
memenuhi kebutuhan masyarakat. Adapun pembangunan infrastruktur yang dimaksud meliputi pembangunan jalan raya, pembangunan gedung sekolah, pembangunan tempat beribadah, pembangunan tol, pembangunan pasar, pembangunan rumah sakit, perluasan jalan raya bahkan pembangunan tempat-tempat hiburan seperti taman kota, mall, arena bermain outbond dan gedung bioskop.

Salah satu pembangunan infrastruktur yang dibutuhkan oleh suatu negara yang jumlah penduduknya semakin bertambah adalah pembangunan jalan raya dan jalan tol. Hal ini dirasa sangat penting karena dengan pembangunan jalan raya dan jalan tol dapat mempercepat waktu perjalanan dan mempersingkat jarak tempuh.

Salah satu pembangunan ruas jalan tol yang sedang dibuat oleh pemerintah adalah proyek pembangunan tolCisumdawu, yang dimulai sejak tahun 2012 sampai sekarang. Pembangunan tolCisumdawu bertujuan untuk mempersingkat waktu tempuh antar kota Sumedang dan sekitarnya bahkan antara kota Bandung dengan bandara Kertajati menjadi lebih singkat waktu perjalanannya. Pembuatan tol ini melintasi wilayah Cileunyi-Sumedang, Cirebon daerah Dawuan, maka disingkat menjadi Cisumdawu. Pembangunan jalan ini banyak membawa dampak bagi penduduk sekitar, baik dampak positif maupun dampak negatif.

Dampak negatif dari pembangunan tolCisumdawu ini adalah, penduduk yang tinggal di sekitar wilayah Cadas Pangeran (ruas jalan sebelah luar jalan tol), yang bermata pencaharian sebagai pedagangpedagang kecil kini mengalami fase sepi pembeli, karena orang-orang lebih memilih untuk menempuh melalui jalan tol apabila ingin bepergian ke kota Sumedang.

Dampak positifnya adalah meningkatnya perekonomian penduduk sekitar wilayah pembangunan phase 2 tol Cisumdawu. Hal ini dikarenakan, harga jual tanah sekitar pembangunan tol Cisumdawu meningkat 8 kali lipat. Semula harga jual tanah 1 tombak (14 meter persegi) paling tinggi hanya sekitar Rp 600.000 per meter persegi kini mencapai Rp 1-5 juta per meter persegi. Selama proses pembangunan penduduk sekitar phase 2 pembangunan tol $\mathrm{C}$ is umdawu mempunyai tambahan mata pencaharian. Penduduk sekitar diberdayakan untuk berprofesi menjadi jasa memasak, jasa cuci gosok baju karyawan proyek, jasa kebersihan mess karyawan proyek, jasa tambahan security, jasa tenaga harian gudang pelaksana survey, jasa tambahan sebagai mandor dan subkon lokal, jasa tukang kebun dan jasa sebagai flagman (petugas yang mengatur trafik keluar masuk kendaraan proyek dan alat berat seperti deco, eskavator, doser, lojer dan lainnya.

\section{Rumusan Masalah}

Dari penelitian ini, yang akan diangkat sebagai rumusan masalah adalah:

a. Apa dampak pembangunan tol Cisumdawu phase 2 bagi perekonomian penduduk sekitar saat proses pembangunan sedang dilaksanakan.

b. Apa dampak pembangunan tol Cisumdawu phase 2 bagi perekonomian penduduk sekitar setelah phase 2 selesai dibangun.

\section{Tujuan Penelitian}

Dalam penelitian ini tujuannya adalah:

a. Untuk mengetahui dampak pembangunan tol Cisumdawu phase 2 bagi perekonomian penduduk sekitar saat proses pembangunan sedang dilaksanakan.

b. Untuk mengetahui dampak pembangunan tol Cisumdawu phase 2 bagi perekonomian penduduk sekitar setelah selesai pembangunan. 
Manfaat Penelitian

Manfaat dari penelitian ini adalah:

a. Manfaat akademis: dapat mengaplikasikan dan mengembangkan keilmuan yang telah didapat dalam memberikan penjabaran analisis.

b. Manfaat praktis: hasil penelitian ini dapat dijadikan referensi bagi keilmuan terkait baik secara langsung maupun tidak langsung. Dan dapat memberikan manfaat bagi pihak-pihak terkait.

\section{TINJAUAN PUSTAKA}

\section{Teori Ekonomi Pembangunan}

Dalam penelitian ini, peneliti menggunakan beberapa teori sebagai landasan yang nantinya dipergunakan untuk menganalisis permasalahan yang ada. Beberapa ahli menyampaikan pendapatnya mengenai definisi ekonomi pembangunan, diantaranya adalah yang disampaikan oleh Profesor Simon Kuznets yang mengatakan bahwa ekonomi pembangunan adalah kemampuan suatu negara untuk menyediakan barang-barang yang dibutuhkan oleh penduduknya, dalam jangka Panjang. Sementara Sukirno (2006) menyampaikan pendapatnya mengenai definisi ekonomi pembangunan, yaitu suatu proses usaha dalam meningkatkan pemasukan atau pendapatan perkapita suatu negara dengan cara mengolah potensi ekonomi menjadi bentuk riil. Menurut Lincolin Arsyad (2010), ilmu yang mempelajari mengenai masalah-masalah ekonomi di negara berkembang dengan berbagai kebijakan yang perlu dilakukan untuk mewujudkan pembangunan.

Todaro (2000) menyampaikan definisi pembangunan ekonomi yaitu suatu proses multidimensional yang melibatkan perubahan-perubahan besar dalam struktur sosial, sikap masyarakat dan lembaga-lembaga nasional termasuk pula percepatan atau akselerasi pertumbuhan ekonomi,

pengurangan ketidakmerataan dan kemiskinan absolut. Keyfit dan Nitisastro (1997) mengatakan bahwa tujuan akhir pembangunan ekonomi suatu negara adalah

memperoleh susunan ekonomi sedemikian rupa sehingga dapat terjamin suatu tingkat hidup yang setinggi-tingginya untuk semua warga negaranya. Dalam setiap pembangunan yang dilakukan oleh pemerintah sasarannya adalah pemerataan pembangunan dengan hasil-hasilnya untuk menuju tercapainya sila kelima yaitu keadilan sosial bagi seluruh rakyat Indonesia.

\section{Teori Pertumbuhan Ekonomi}

Secara global pengertian dari teori pertumbuhan ekonomi adalah faktorfaktor apa saja yang menentukan kenaikan output perkapita dalam jangka panjang dan penjelasan, mengenai bagaimana faktorfaktor tersebut berinteraksi satu sama lain sehingga terjadilah proses pertumbuhan. Ada pula pendapat yang menyimpulkan bahwa pertumbuhan ekonomi adalah peningkatan kegiatan ekonomi masyarakat

yang menyebabkan peningkatan jumlah produksibarang dan jasa di suatu negara pada periode tertentu.

Teori pertumbuhan ekonomi klasik adalah teori mengenai pertumbuhan ekonomi dari sudut pandang pertumbuhan penduduk. Seperti yang disampaikan oleh Adam Smith, yaitu suatu perekonomian akan tumbuh dan berkembang apabila ada pertambahan penduduk.

Teori pertumbuhan ekonomi neo-klasik menguraikan bagaimana tingkat pertumbuhan ekonomi bisa stabil hanya jika tiga kekuatan ekonomi ikut andil, yaitu tenaga kerja, modal dan teknologi. Di sini teknologi sangat 
berperan karena menurut teori ini suatu pertumbuhan ekonomi sudah dapat dipastikan akan memerlukan dan harus didukung oleh kemajuan teknologi. Dengan kata lain, perubahan teknologi berpengaruh secara signifikan terhadap fungsi ekonomi secara keseluruhan.

\section{Penduduk}

Ada beberapa pengertian penduduk yang diberikan oleh para ahli. Diantara pendapat-pendapat tersebut adalah (brainly.co.id):

a. Jonny Purba memberikan definisi penduduk sebagai orang secara pribadi, Bersama keluarga, anggota masyarakat, warga negara yang tinggal pada suatu tempat dalam waktu tertentu.

b. Mamat Rahmat dan Ahmad Yani, mengatakan penduduk adalah unsur terpenting dalam suatu wilayah atau negara.

c. Agung Feryanto, Tri Haryanto, Suwardi dan Waluyo menyampaikan definisi penduduk bahwa merupakan potensi sekaligus beban untuk suatu wilayah atau negara.

d. Simanjuntak, menyampaikan pengertian penduduk sebagai mereka yang bertempat tinggal pada suatu negara.

e. UUD 1945 Pasal 26 ayat (2), penduduk adalah warga negara Indonesia dan orang asing yang bertempat tinggal di Indonesia.

f. Nudirman berpendapat penduduk adalah orang yang menetap dan berdomisili pada suatu negara.

g. A.Rahman dan Srijanti, berpendapat penduduk adalah sekumpulan orang yang tinggal pada suatu wilayah dan yang tidak mempermasalahkan status kewarganegaraannya.

h. Kartomo Wirosuhardjo, penduduk adalah orang yang menduduki wilayah.tertentu

terlepas

daristatus wargane gara.

\section{Pembangunan Manusia}

Pembangunan secara infrastruktur yang membawa dampak positif dan dampak negatif bagi perekonomian penduduk, hendaknya diikuti dengan pembangunan manusia seutuhnya. Sesuai dengan apa yang didefinisikan dari United Nation Development Program (UNDP) memberikan definisi pembangunan manusia sebagai proses untuk memperluas pilihan-pilihan bagi penduduk (Human Development Report, 2001), dalam arti bahwa manusia diberi pilihan yang lebih banyak dalam memenuhi kebutuhan hidupnya baik yang menyangkut ekonomi, sosial dan budaya.

Keberhasilan pembangunan manusia dinilai dari seberapa besar permasalahan yang menyangkut kehidupan masyarakat/penduduk dapat teratasi. Beberapa permasalahan mendasar itu diantaranya, masalah pengangguran, masalah kemiskinan, menurunnya moral manusia. Menurut UNDP, indikator keberhasilan pembangunan manusia meliputi 1) pemerataan, yaitu pemerataan hasil pembangunan, pemerataan untuk dapat mengakses dengan mudah kebutuhan primer manusia (sandang, pangan, papan), kebutuhan akan pelayanan kesehatan yang kini sudah melalui BPJS, kebutuhan akan pendidikan yang kini sudah berjalan dengan program bebas SPP untuk sekolah-sekolah negeri, 2) mampunya setiap manusia untuk berproduktivitas sesuai dengan kreatif dan inovatifnya masing-masing., 3) pemberdayaan, yaitu pertumbuhan dan pembangunan SDM yang diupayakan oleh pemerintah. Menurut Mirza (2012), bahwa jika kinerja ekonomi ingin dicapai lebih baik, maka modal utamanya adalah sumber daya manusia yang berkualitas. 


\section{METODOLOGI PENELITIAN}

\section{Waktu dan Tempat Penelitian}

Penelitian ini dimulai sejak awal Maret 2021 sampai April 2021. Tempat penelitian adalah di Dusun Gawiru, Desa Girimukti, Kecamatan Sumedang Utara, Kabupaten Sumedang-Provinsi

Jawa Barat.

\section{Metodologi dan Paradigma Penelitian}

Menggunakan metode kualititaf dengan pendekatan in-depth interview.

\section{Narasumber}

Penelitian ini menggunakan teknik wawancara mendalam (indepth interview). beberapa narasumber yang diwawancarai adalah:

a. Ketua Dusun Gawiru

b. Beberapa penduduk Dusun Gawiru yang terdampak langsung secara ekonomi dengan adanya proses pembangunan Tol Cisumdawu phase 2, yang melewati wilayah tempat tinggal mereka.

c. Data-data pendukung lainnya yang relevan dengan penelitian ini.

\section{Profil Dusun Gawiru}

Dusun Gawiru ini merupakan wilayah yang masuk ke dalam Desa Girimukti, Kecamatan Sumedang Utara,

Kabupaten Sumedang-Provinsi

Jawa Barat. Desa Girimukti memiliki 14 dusun yaitu Dusun Cijeungjing, Dusun Gawiru, Dusun Bojongloa, Dusun Jamban, Dusun Cibenda, Dusun PR, Dusun Garnus, Dusun Sukaluyu, Dusun Bojong Kondang, Dusun Cihanyir, Dusun Pasir Kuning, Dusun Cibaros, Dusun Binong dan Dusun Panunjang.

Wilayah Desa Girimukti ini terdiri dari 14 RW dan 44 RT. Dari ke-14 dusun tersebut peneliti memutuskan hanya meneliti Dusun Gawiru, dengan pertimbangan bahwa sampai saat penelitian ini digarap, pembangunan tol Cisumdawu phase 2 masih berlangsung. Berikut di bawah ini dapat kita lihat letak geografis Dusun Gawiru. Berikut adalah gambar peta wilayah Desa Girimukti-Sumedang Jawa Barat.

\section{PEMBAHASAN}

\section{Gambar 1}

Wilayah Desa Girimukti - Sumedang

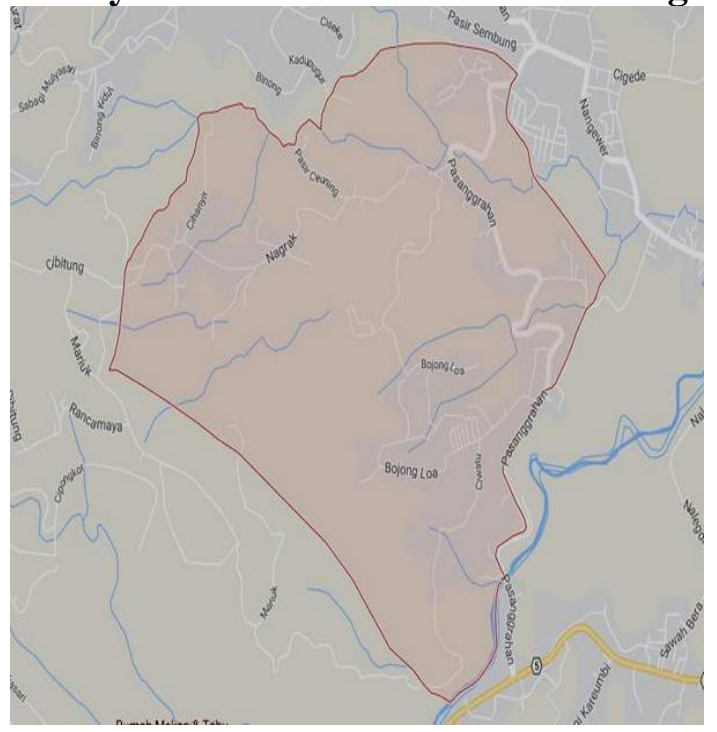


Gambar 2

Peta Dusun Gawiru

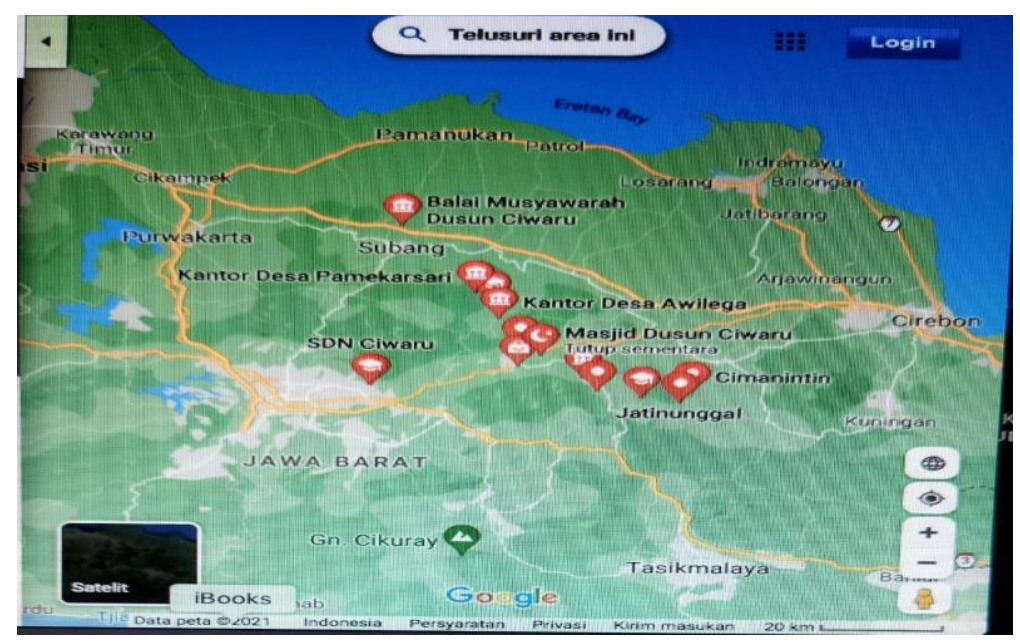

Sebagian besar penduduk Desa Girimukti bermata pencaharian sebagai petani, baik sebagai petaninya (pemilik) maupun sebagai buruh tani (membantu menggarap sawah/ladang orang). Lahan persawahan di Desa Girimukti memiliki produktivitas yang bagus dalam menghasilkan produk utama berupa padi. Produksi padi juga dihasilkan oleh lahan huma berupa padi gogo. Selain menghasilkan padi, juga menghasilkan berbagai jenis palawija seperti jagung, ubi jalar, ubi kayu, talas, kacang gondolo dan kacang tanah.

Sejak adanya proses pembangunan tol Cisumdawu phase 2 yang melewati Desa Girimukti, khususnya Dusun Gawiru, banyak perubahan yang secara tidak langsung terjadi sebagai akibat dari proses pembangunan tersebut. Dampak pembangunan tol Cisumdawu phase 2 ini. Salah satu diantaranya yang paling menonjol adalah perubahan perekonomian. Baik yang berdampak positif maupun negatif.

\section{Hasil Penelitian}

Dampak pembangunan tol Cisumdawu phase 2 ini, membawa dampak negatif, diantaranya perekonomian penduduk sekitar jalan Cadas Pangeran, mengalami kemerosotan dalam hal penghasilan. Mereka yang bermata pencaharian sebagai pedagang-pedagang kecil, yang dulunya ramai pembeli yang hendak menuju dan dari kota Sumedang, kini mengalami fase sepi pembeli. Hal ini dikarenakan orangorang yang akan menuju dan dari Sumedang, lebih memilih melewati tol Cisumdawu karena menghemat waktu perjalanan dan jarak tempuh. Banyak pedagang-pedagang kecil sepanjang Cadas Pangeran, mengeluh sepi pembeli yang sangat berdampak pada menurunnya penghasilan keluarga.

Dampak pembangunan tol Cisumdawu phase 2 yang berdampak positif adalah terbukanya peluang kerja bagi penduduk sekitar pembangunan tol Cisumdawu. Selama proses pembangunan tol ini, para karyawan proyek tinggal di beberapa wilayah yang dilalui proyek pembangunan tol. Dengan bertempat tinggal sementara para karyawan proyek di sekitar wilayah pembangunan tol, otomatis membuka peluang pekerjaan bagi penduduk setempat, khususnya di wilayah Dusun Gawiru.

Pihak pembuat jalan tol baik pemerintah maupun swasta, memberdayakan 
penduduk sekitar proyek untuk bekerja sesuai dengan bidang pekerjaan yang dibutuhkan. Adapun bidang pekerjaan yang dibutuhkan adalah jasa memasak/juru masak, jasa cuci-setrika baju, jasa membersihkan mess dan kantor proyek, jasa petugas harian gudang (pengecekan persediaan barang-barang material), pelaksana survey lapangan, security, mandor, subkon lokal, flagman (pengatur kendaraan keluar masuk proyek baik kendaraan biasa maupun alat berat seperti deco, eskavator, doser, lojer dan lainnya. Berikut tampak kantor dan mess karyawan proyek (PT WIKA) yang dibangun secara permanen di atas tanah warga yang telah dibeli dari warga, yang berlokasi di Jalan Pesanggrahan Dusun Gawiru RT02, RW 08, yang berhadapan dengan Posyandu Beringin Desa Girimukti, Kecamatan Sumedang Utara, Kabupaten Sumedang.

Gambar 3

Kantor Wijaya Karya

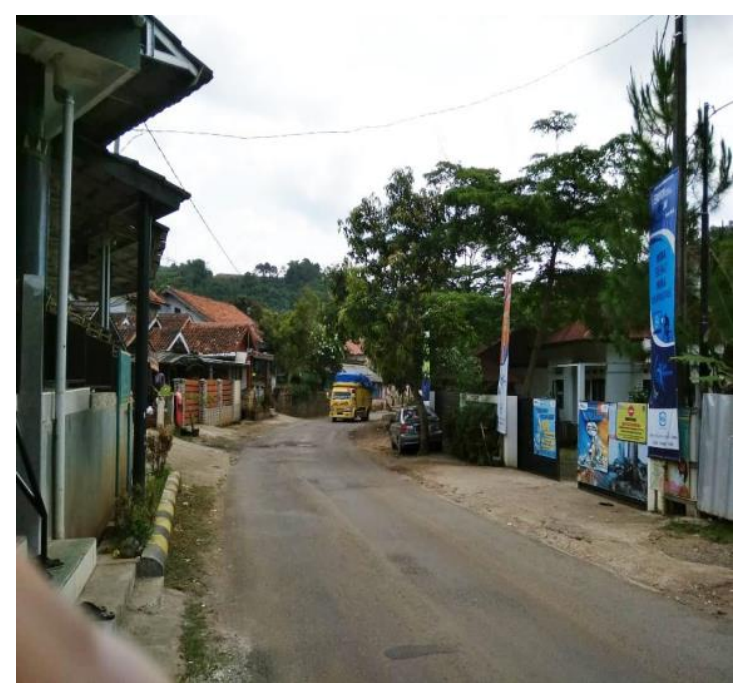

Sumber: data pribadi

Gambar 4

Asrama Karyawan PT Wijaya Karya

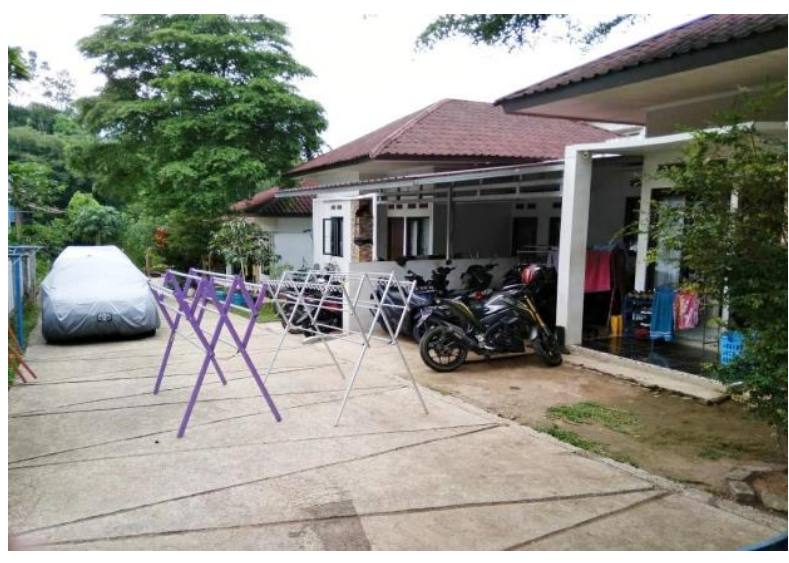

Sumber: data pribadi 
Berikut hasil wawancara peneliti dengan beberapa narasumber dalam hal ini penduduk Dusun Gawiru yang diberdayakan dengan adanya proyek pembuatan jalan tol ini:

Seorang ibu berusia sekitar 45 tahun, sebut saja ibu Ani. Awalnya ibu Ani hanya seorang ibu rumah tangga biasa yang tidak bekerja, sementara suaminya adalah buruh tani. Mereka dikaruniai 2 orang anak yang masih duduk di bangku Sekolah Dasar. Sejak adanya pembangunan jalan tol Cisumdawu phase 2 ini, beruntung ibu Ani yang pandai memasak diberdayakan sebagai juru masak dengan beberapa ibu lainnya. Ibu Ani kini memiliki penghasilan tetap setiap bulannya, yang dapat membantu

perekonomian keluarga.

Seorang ibu muda berusia sekitar 32 tahun, sebut saja ibu Ida. Sama halnya dengan ibu Ani, ibu Ida pun hanya sebagai ibu rumah tangga biasa. Hanya sesekali membantu suaminya yang berprofesi sebagai buruh tani, apabila musim panen tiba. Ibu Ida dikaryakan sebagai tenaga cuci-setrika dengan beberapa ibu lainnya. Tidak terlalu berat pekerjaan ibu Ida karena dibantu dengan mesin cuci. Penghasilan yang ibu Ida terima, sebagian dipergunakan untuk mencukupi kebutuhan rumah tangga dan sebagian lag $i$ ditabung. Terkadang Pun ibu Ida membuat cemilan makanan sore seperti pisang goreng, tahu isi, tempe goreng, tape goreng, bakwan untuk para karyawan.

Seorang pemuda lajang berusia sekitar 25 tahun, sebut saja Budi, diberdayakan sebagai tenaga security, mengaku merasa senang dengan pekerjaannya sekarang. Dulu sebelum proyek ini ada, Budi adalah seorang pekerja serabutan. Artinya pekerjaan apapun yang ada, yang membutuhkan tenaganya, diterima selama pekerjaan tersebut halal. Kini dengan statusnya sebagai tenaga security, menerima penghasilan yang lebih dari cukup untuk membantu pemenuhan kebutuhan hidup orangtuanya dan 2 adiknya.

Seorang pria berusia sekitar 45 tahun, sebut saja Agus, yang dulunya berprofesi sebagai tukang bangunan, kini diberdayakan sebagai mandor. Berdasarkan hasil wawancara, Agus menyatakan merasa senang sekali dipekerjakan sebagai mandor, karena 
mempunyai penghasilan yang lebih dari cukup untuk memenuhi kebutuhan hidup anak dan istrinya.

Pengalaman sebagai flagman yang dijalani oleh Iwan (bukan nama sebenarnya), yang baru berusia 20 tahun, dirasa sangat menyenangkan. Karena hanya bertugas mengatur lalu lintas keluar masuk kendaraan proyek, Iwan mempunyai penghasilan tambahan disamping sebagai buruh tani. "Senang mbk, karena kerjanya hanya mengatur keluar masuk kendaraan proyek, saya dikasih rompi, topi proyek, gagah rasanya mbak kalau saya pakai itu."

Menurut Ketua Dusun Gawiru, dengan adanya pembangunan

tol Cisumdawu phase 2 ini, banyak memberikan perbaikan dalam segi perekonomian penduduk sekitarnya. Angka ratarata penghasilan penduduk mengalami kenaikan yang signifikan, kehidupan penduduk menjadi lebih sejahtera. Namun lebih lanjut Ketua Dusun Gawiru menyampaikan kekhawatirannya,

\section{bagaimana}

perekonomian

penduduknya jika pembangunan proyek tol Cisumdawu phase 2 ini telah usai, yang artinya penduduk sekitar akan kehilangan pekerjaan mereka selama mereka diberdayakan..

Pembangunan jalan tol Cisumdawu phase 2 ini yang melewati Dusun Gawiru, jika dikaitkan dengan teori Todaro (2000) mengenai teori ekonomi pembangunan, bahwa Dusun Gawiru tengah mengalami perubahan-perubahan pada struktur sosial. Hal ini terlihat dari harga tanah yang meningkat sebanyak 8 kali lipat dari harga tanah sebelum adanya pembangunan tol Cisumdawu phase 2, yang otomatis dapat meningkatkan taraf hidup dan status sosial penduduknya.

Berdasarkan teori pertumbuhan ekonomi, adanya peningkatan pendapatan penduduk Dusun Gawiru yang dikaryakan untuk membantu dalam proses pembangunan tol Cisumdawu phase 2 ini. Dan juga terlihat adanya interaksi yang saling menguntungkan antara para karyawan proyek dengan penduduk Dusun Gawiru.

Pembangunan secara infrastruktur, hendaknya diikuti pula dengan pembangunan manusia seutuhnya. Karena 
pertumbuhan ekonomi selalu dikaitkan dengan pembangunan manusia.

Dengan memberdayakan penduduk sekitar dalam membantu proses pembangunan jalan tol Cisumdawu phase 2, maka hal ini turut membantu indikator keberhasilan pembangunan manusia, seperti yang disampaikan oleh UNDP dan Mirza..

\section{KESIMPULAN DAN SARAN}

\section{Kesimpulan}

Dari penelitian yang dilakukan oleh peneliti, maka dapat disimpulkan sebagai berikut:

adanya dampak negatif dan dampak positif selama proses pembangunan tolCisumdawu phase 2 ini. Adapun dampak positifnya adalah:

1. Naiknya harga tanah sekitar wilayah yang dilalui tolCisumdawu phase 2 ini, dari harga awal tanah 1 tombak (14 meter persegi) hanya sekitar Rp
600.000 kini naik menjadi Rp 1 jt sampai Rp 5 juta tergantung lokasi tanahnya.

2. Banyak masyarakat yang diberdayakan untuk membantu pekerjaan di luar pekerjaan proyek yaitu jasa cuci-setrika baju, jasa membersihkan mess dan kantor proyek, jasa petugas harian gudang (pengecekan persediaan barangbarang material), pelaksana survey lapangan, security, mandor, subkon lokal, flagman.

3. Perekonomian penduduk sekitar mengalami peningkatan dari sebelum adanya pekerjaan proyek pembangunan tol Cisumdawu phase 2.

4. Dampak negatifnya adalah sepinya pembeli bagi para pedagang kecil sekitar Cadas Pangeran, karena kini orang lebih senang melewati tol ini untuk mempersingkat waktu dan jarak tempuh.

\section{Saran}

Hendaknya ada pemikiran dan rencana lain bagi pemerintah agar para pedagang kecil sekitar Cadas Pangeran mempunyai mata pencaharian lain selain sebagai pedagang. 


\section{DAFTAR PUSTAKA}

Arsyad, Lincoln. 2010. Ekonomi

Pembangunan. Yogyakarta: Unit Penerbit dan Percetakan

STIM YKPN Yogyakarta

Keyfitz, Nathan dan Nitisastro, Widjoyo, 1997. Soal Kependudukan dan

Pembangunan

Indonesia, P.T. Pembangunan,
Sadono, Sukirno. 2006. Ekonomi

Pembangunan: Proses, Masalah, dan Dasar

Kebijakan.

Jakarta: Prenada Media Group.

Todaro, Michael P. 2000. Pembangunan

Ekonomi. Jakarta: PT. Bumi Aks

Jakarta 